\title{
大菱形骨の骨折及び脱臼の治療経験
}

\author{
国立小浜病院整形外科 \\ 長 谷 芳 文 \\ 国立長崎中央病院整形外科 \\ 平 野 英 二 \\ 長崎大学整形外科 \\ 今 村 宏太 郎 \\ 千綿病院整形外科 \\ 千 綿 国 彦
}

\section{Fracture and Dislocation of the Trapezium - Report of Three Cases-}

by

\author{
Yoshifumi Nagatani
}

Department of Orthopedic Surgery, National Obama Hospital Obamacho, Japan.

Eiji Hirano

Department of Orthopedic Surgery, National Nagasaki

Chuo Hospital, Omura, Japan.

Kotaro Imamura

Department of Orthopedic Surgery, Nagasaki University School

of Medicine, Nagasaki, Japan.

Kunihiko Chiwata

Chiwata Orthopedic Clinic, Nagasaki, Japan.

Three cases including a dorsal fracture-dislocation, a vertical fracture associated with fracture of the second metacarpal and an old complete volar dislocation are presented. The mechanism of these fractures is usually a direct blowon the wrist or a fall with the hyperextended hand in radial deviation. Our all cases were seen after violent, direct trauma. Slightly displaced vertical fracture may respond well to closed reduction and casting. Although for the severe fracture-dislocation or complete dislocation, it is believed that anatomical reduction and internal fixation are indicated to provide the earliest possible restoration of motion of thumb with the least possibility of subsequent traumatic arthritis and avascular necrosis.

はじめに

手根骨々折のうち大菱形骨の骨折及び脱臼は稀なも のとされ，1910年 Kindl が Bennett骨折に合併した大 菱形骨の骨折を発表して以来，欧米ではCordrey， Mcclain らの報告がみられるが，本邦での報告例は少
ない. 今回, 我々は大蔆形骨の背倒への脱臼骨折 1 例, 第 2 中手骨基部の骨折を伴なったvertical fracture 1 例，陳旧性の掌側への単独脱的 1 例の計 3 例を経䮖 したので，文献的考察を加えて報告する. 
症

例

症:例 I：20才, 男, 大学生

現病糜：バイク走行中，右手でアク七ルを据ったま まトラックに湤突した。直後より，右手闺節㳳倒の疼 痛及び指の連動制限を認め近医老受衫した。X線像 にて右大莼形骨の脱印骨折を指摘され，受伤後 3 日日 に当科を紹介され受衫した。

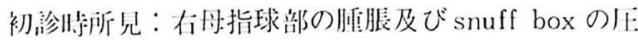

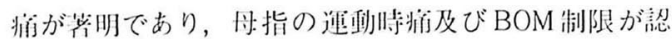
められた。

X線所胃：大苳形骨の 4 つの䍏節面が写し出される

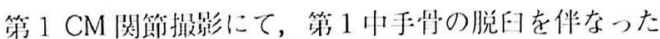

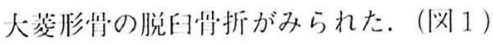

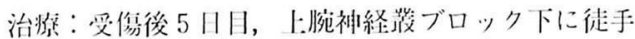

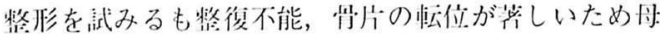
指機能を重視して微血的整徣術老施行した。短丹指神

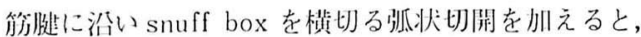
大菱形高は甞倒，尺但に小骨片を残して背倒へ脱臼し

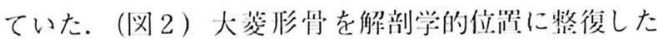
後, Kirschner 鋼線 3 本にてST, TT CM 関節を阔 定，舟指外忶位にて 4 週間ギプス周定した。(网 3 a)

術後 1 年半を経過古るも舟指の疼涫, ROM 制限はな く，X線像でも大曼形骨の各関節面は良く保たれてい る. (网 3 b)

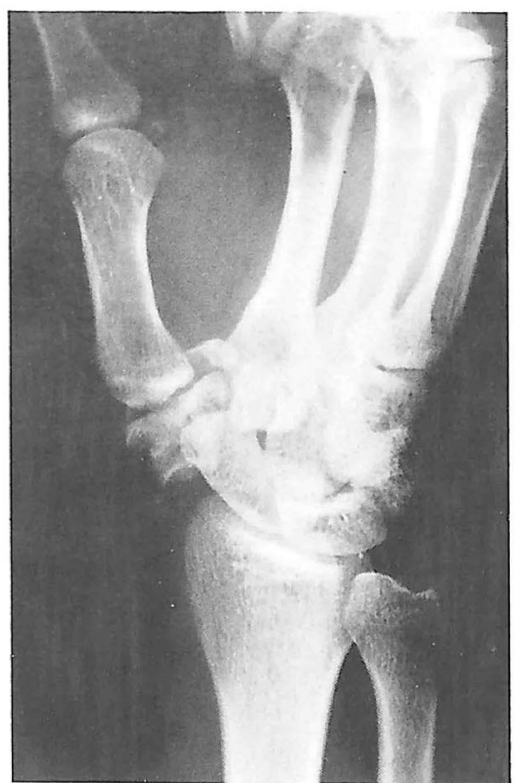

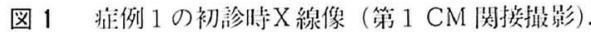
第 1 中手荝の脱且を伴なった大荾形骨の背 傅への悦田骨折が胃られる.

症例 $2 ： 37$ 才, 男, 连転手

現病麻：作業中，左手背部㳳僛に大きな石が落下し てきて受㑺. 左手関節嗝のための近医受䇏，X線像に て左大莐形骨々折を指摘され，当科紹介となる.
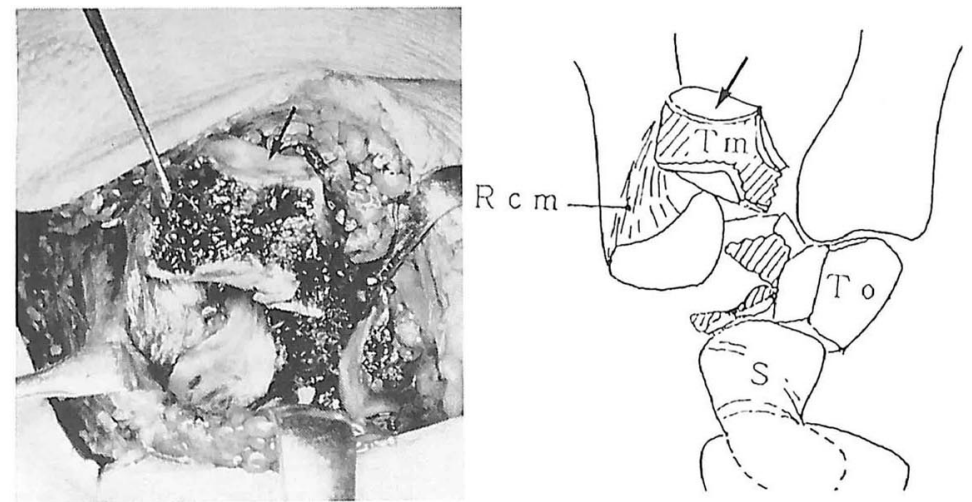

图 2 注例 1 の術中所见

$\mathrm{Tm}$ : Trapezium

To : Trapezoid

$S$ : S caphoid

Rcm: Radial carpometacarpal ligamen

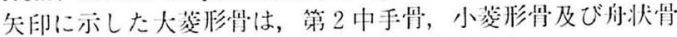

の阅筫面に小南片を残し，背側へ脱的していた。 


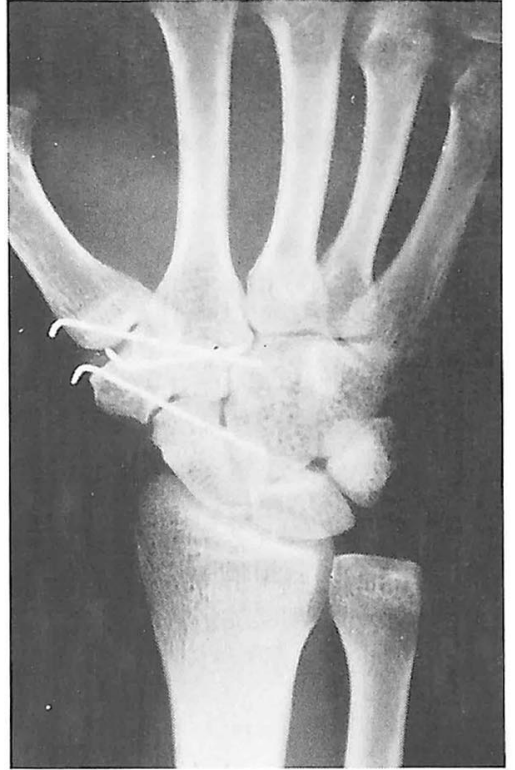

図 $3 \mathrm{a}$ 症例 1 の術直後のX 線像, 大落形骨 の各関節面は良く整後されている.

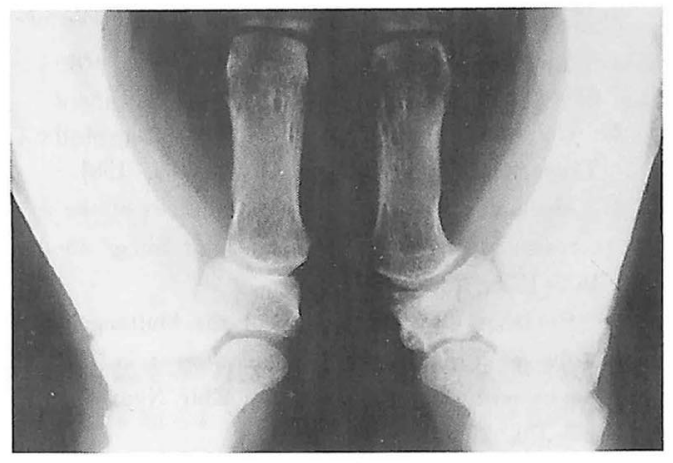

図 $3 b$ 症例 1 の術後 1 年半のX 線像

関節裂隙は比較的良く保たれている.

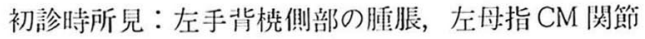
の ROM 制限が垫められた。

X線所見：左大荾形骨のvertical fracture と第 2 中手骨基部の骨·折を吠める。（図 4 a)

治療：骨片の転位もなく CM 関節面も比較的良く保 たれていたので母指外転位にて 4 週間のギプス周定を 行なった.

術後, 5 ヶ月の時点で左母指の ROM 制限なく, X 線像でも骨癒合良好であった。(汹4b)

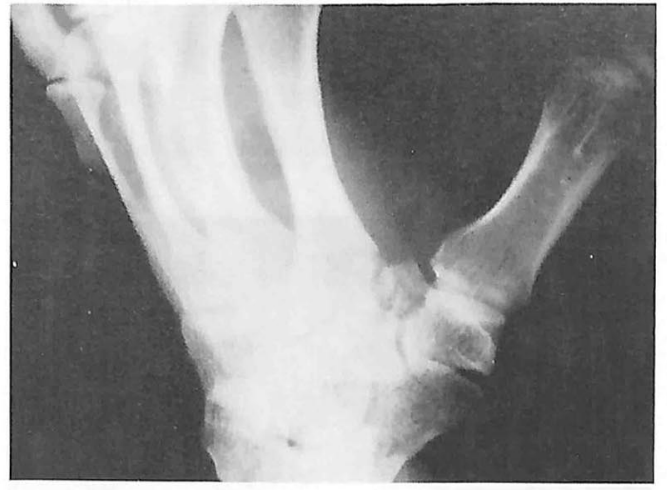

図 4 a 症例 2 の初郝步: X 線像

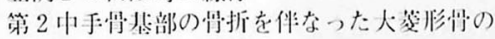
vertical fracture が胃られる.

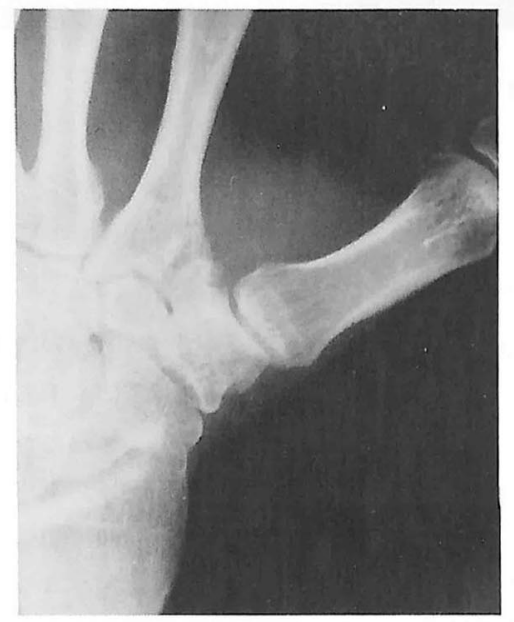

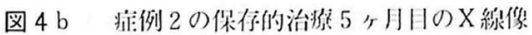
骨誓合は良奵である。

症例 $3: 43$ 才, 男, 搌䓉只

現病歷：約20年前，印刷機に存手をはさまれて受㑺，

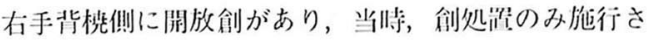

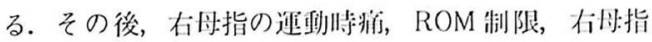
及び示指のしびれ感が持続するため，近医を受衫する も手関節捻挫として放罚されていた。最近になって别

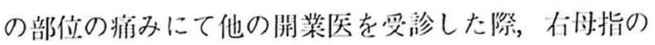
変形及びROM 制限を指摘され，X線倣影を施行した

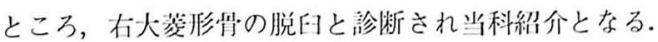

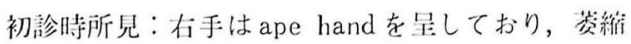
した甘指球部内に具性:隆起を触れる. 
CM 関節の ROM は莞しく制限され，手根管为湥群 の合併も認められた。

X線所见：前内㒋への大菱形骨の脱斗が胃られた。

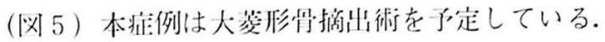

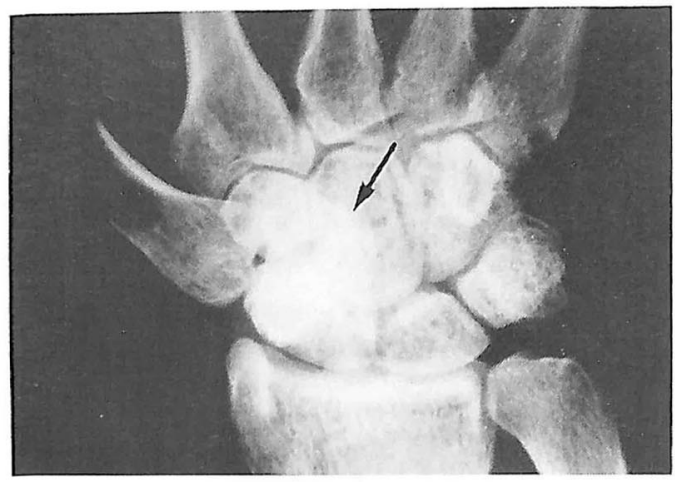

図 5 将例 3 のX線像

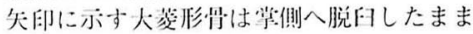
約20作間㸡淌さされていた。

考察

手根胃々折の中でも大䒾形骨の骨折及び脱的は稀で あり，Cordrey らによると同部の省折は全手根省々折 の約 $5 \%$ にすぎない，骨折に関しては，本邦においても 1964年に山内が 1 例報告して以来，伊滕，永井，星， 芹滕，田中らの郝告がみられるが，脱臼に咸しては杉 はらの報告があるにすぎない，発生のメカニズムとし ては直道外力によるものと，分達外力によるものがあ

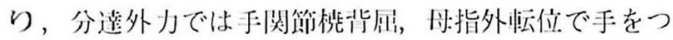
いな際に，大夋形尖が第 1 中手省と喍骨苳状突起間に はささまれて起こるとされているが，我々の症例 1 は手

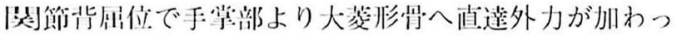
て発生したものと学えられた。症例 2 及び 3 も病歴よ

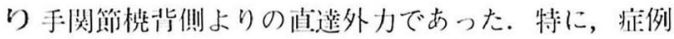

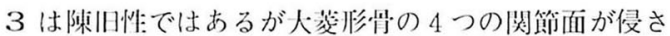
れた単独の完全脱罒であり，完全脱臼は直達外力によ つてのみ起こるとするBoe'の意胃を支持するもので あった。

治㷧に威しては症例 2 のうな枟位の少ない症例で は約 4 週間のギプス闻定で良奵な成結が得られるが，

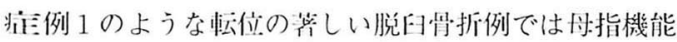

の早期回復及び将来の関節症の発生防止のため微血的 な解剖学的整復が望ましい，また，症例 3 の如き陳旧 吽の脱兒においては avascular necrosis の可能性も あり，大苳形骨摘出術の適応であろうと考えている.

ま と め

1.手根骨の税臼及び骨折の中でも稀であるとされ る大葼形骨の背倒への脱臼骨折 1 例, 第 2 中手骨基部 の啽折を伴なったvertical fracture 1 例，陳旧性の 学側への単独脱臼 1 例の計 3 例について述べた.

2. 大荾形悬の骨折において転位の軽度な例では保 存的燋法でも良好な成縝を得る事ができるが，転位の 莎しい脱臼骨折例では母指機能の障害を呈し，さらに 学側脱田例では手根管症侯群を合住するものがあり， 解剖学的整復が望ましい。

\section{文献}

1) Boe S.: Dislocation of the Trapezium. Acta Orthop. Scand. 50, 85-86, 1979.

2) Cordrey LJ et al: Management of Fractres of the Greater Multangular. J. Bone Joint Surg. 42-A : 1111-1118, 1960.

3) Goldberg I et al: Complete Dislocation of the Trapezium. J. Hand Surg. 6: 193-195, 1981.

4) Mcclain EJ et al: Missed Fractures of the Greater Multangular. J. Bone Joint Surg. 48-A: 1525-1528, 1966.

5) Peterson $\mathrm{CO}:$ Dislocation of the Multangulum Majus of Trapezium and its Tratment in Two Cases with Extirpation. Arch Chir Neerl 2: 369-376, 1950.

\section{質 問福大筑紫病院 松崎 昭夫}

脱臼機転につき，ハンドル握った网を示され直達外 力とされたが介達外力を全く否定された考えは？

解 答国立長崎中央病院 平野 英二 症例 1 は背側脱臼であり，手関節が桲背属位で母指 が外転伸展位では手骨よりの介達外力を受けるとこの 肢位において大荾形骨は掌側が広い台形形となってお り，㳳骨形状突起との間にはさまれるので掌側へ脱臼 して背侧へは脱臼し難いと考える. 